I Universidade Federal de Minas Gerais (UFMG), Núcleo de Pesquisa,

Documentação e Memória, Belo Horizonte, MG, Brasil

marcelatelleselian@gmail.com

https://orcid.org/o0oo-000I-6216-8069

Marcela Elian Lima'

\title{
A GRANDE ESPERANÇA: POLÍTICA AGRÁRIA NA CANÇÃO SERTANEJA DURANTE A DITADURA MILITAR (1964-1985)
}

Por mais de um século, a canção popular brasileira funciona como suporte de circulação de ideias para o debate político, social e comportamental sobre o país. Em muitas canções, o tema abrangente é o Brasil: seu caráter, sua história, costumes, expectativas. Por sua vez, sociólogos, historiadores, cientistas políticos e jornalistas dedicaram uma escuta atenta a essa diversificada produção musical, procurando refazer os passos de compositores e intérpretes. Esses estudiosos se apossaram de citações, alegorias, intertextualidades, melodias, ritmos, ruídos e pausas para com eles extrair sentidos, projetos, sonhos, sentimentos que os auxiliassem na interpretação de um Brasil fragmentado geograficamente, politicamente diversificado, grande e complexo demais para uma única trilha sonora.

Dos muitos gêneros musicais que compõem nosso cancioneiro, o sertanejo está entre os mais propriamente populares, como o funk, o forró, o brega e o axé não só por seu grande êxito comercial, como também pela origem social de grande parte de seus artistas. Muitos deles vieram da roça, trabalharam em fazendas, moraram em zonas rurais. Tinham profundo conhecimento da vida no campo, mas, guiados pela canção, se aventuraram para bem adiante de seus lugares de origem, conhecendo e dando a conhecer os muitos fragmentos de Brasil aos quais procuravam pertencer. E, como ocorreu com tantos outros compositores - de Noel Rosa a Chico Buarque, de Sinhô a Zeca Pagodinho, de Chico Science a Milton Nascimento -, esses também foram acompanhados pela escuta interessada de estudiosos, em diferentes períodos. 
Um dos primeiros foi o sociólogo José de Souza Martins, que no capítulo "Música sertaneja: a dissimulação na linguagem dos humilhados", publicado em I975, definiu a canção sertaneja em contraposição à canção caipira. Elaborada nos centros urbanos para consumo, a música sertaneja teria um fim em si mesma. Um produto da indústria fonográfica destinado a um público específico: migrantes rurais nas grandes cidades. A caipira, por sua vez, possuiria vínculo efetivo com o cotidiano de parceiros, meeiros e colonos do interior paulista, por ser utilizada na ritualização das festas e comemorações religiosas. E foi logo avisando: caipira é caipira, sertanejo é sertanejo. Tomar uma coisa pela outra significaria "um profundo desconhecimento de cada um desses tipos de música” (Martins, I975: I04). De modo semelhante, Waldenyr Caldas e José Ramos Tinhorão consideraram a canção sertaneja "um produto da cidade destinado ao consumo de gente ligada pela origem a hábitos e estilos da vida rural" (Tinhorão, 200 I: 45). Produto de uma indústria cultural interessada em explorar o gosto popular "sem nenhuma preocupação com a melhoria do nível cultural de seu público" (Caldas, I977: I6).

Além da contraposição aos ritmos rurais caipiras, outro elemento mobilizado por esses autores na definição da canção sertaneja consistiu nas adaptações melódicas, rítmicas e temáticas ocorridas desde a gravação da primeira moda de viola, por Cornélio Pires, em I929. De acordo com José de Souza Martins, o repertório sertanejo se teria sofisticado ao longo do tempo, ao privilegiar em sua estrutura musical o ponteado sobre o rasqueado, a melodia sobre o ritmo. A gradual preponderância da viola sobre outros instrumentos possibilitou às canções sertanejas expressar o que ele chamou de uma "saudade mais convenientemente burguesa" (Martins, I975: I 26). As letras das canções, por sua vez, passaram a tematizar, com mais frequência, o cotidiano nas grandes cidades "numa nítida demonstração de que a música sertaneja já não pertence mais somente ao meio rural e ao interior; de que ela, agora, é urbana também" (Caldas, I977: 5). Nas palavras de Tinhorão (200I: 46), ao fim da década de I970, estava longe o formato em que se apresentavam "não atores citadinos vestidos de calças remendadas e camisas de xadrez, mas violeiros autênticos de Piracicaba". Essas análises sobre a canção sertaneja foram produzidas entre I975 e I980, período em que a política desenvolvimentista dos governos militares acelerava a urbanização do país, e as cidades se impunham sobre o campo. Quanto mais esvaziado de roças e sertões o Brasil parecia a esses autores, mais difícil discernir seu eco nas canções.

A partir da década de I990, jornalistas, antropólogos, sociólogos, historiadores retomaram algumas das questões propostas pelos estudos anteriores e saíram à procura de caipiras e sertões. Rosa Nepomuceno (I999); Romildo Sant'Anna (2000); Alexander Dent (2009); Alan de Paula Oliveira (2009); Ivan Vilela (20I3); Gustavo Alonso (20I5) são apenas alguns dos autores e autoras que se voltaram para o cancioneiro sertanejo a fim de reafirmar quer seu vín- 
culo com a cultura caipira - não obstante suas adaptações ao formato fonográfico -, quer seu engajamento político, suas qualidades literárias ou de enfatizar a capacidade dessas canções - como de resto todo o cancioneiro popular - de se adequar a diferentes contextos históricos, musicais e geográficos.

É certo que ao migrar dos ritos religiosos, de festa e trabalho para o formato fonográfico algo da cultura caipira se perdeu. A catira se fragmentou no recortado e na moda de viola. No cururu, a dimensão da dança foi atenuada pelo predomínio do desafio, como bem apontado por esses estudos. As modas de viola, toadas, contradanças, valsas, cateretês, rasqueados, emboladas, recortados que rotulavam os discos em 78 rotações de Cornélio Pires, Turma Caipira da Victor, Raul Torres e Serrinha, Mandi e Sorocabinha, nas décadas de I930 e I940, a partir dos anos I960, passaram a ser reconhecidos indistintamente sob o gênero sertanejo. As gravadoras criaram selos especialmente voltados para esse cancioneiro como o "Caboclo", da Continental; "Premier", da RGE, e "Jangada”, da Emi-Odeon (Vicente, 20Io). Palmeira, da dupla Palmeira e Biá, como diretor artístico da gravadora Chantecler, foi o responsável pelo uso do termo sertanejo pela primeira vez na indústria fonográfica. Uma estratégia para diferenciar as canções derivadas dos ritmos rurais do interior de parte dos estados de São Paulo, Minas Gerais, Mato Grosso, Goiás e Paraná - do repertório de Luiz Gonzaga - e dar conta dos novos ritmos e melodias introduzidos pelos artistas do cancioneiro inicialmente formulado por Cornélio Pires. As gravações de guarânias, rancheiras, mariachis, chamamés, boleros e de canções influenciadas pelo rock and roll, ainda que interpretadas por duplas cantando em terças, dizia Palmeira, estavam muito distantes dos ritmos rurais caipiras (Sousa, 2005: I43). Essa distância, porém, não era novidade. Colocou-se no momento da elaboração da primeira moda de viola. Um formato adaptado ao tempo de duração de um 78RPM que pouco manteve dos longos desafios caipiras que varavam noite afora pelo interior e capital paulistas, nas primeiras décadas do século XX.

Esses estudiosos, por sua vez, desde as primeiras páginas, parecem querer nos advertir de que nenhuma canção sertaneja é composta ou cantada por um caipira. Pressupõem sempre um momento anterior ou um lugar mais ao interior, ao qual é necessário voltar para ouvir uma canção composta ou cantada por um caipira. Nesse movimento, o risco é se distanciar de modo radical dos contextos nos quais as canções foram gravadas. De tanto olhar para trás, retomamos o momento inicial da colonização do Brasil - quando tudo seria sertão - à procura do exato instante em que a viola - instrumento por excelência desse cancioneiro - haveria forjado uma gente e uma cultura próprias.

Capitão Furtado, o compositor e sobrinho de Cornélio Pires responsável por revelar em seu programa Arraial da curva torva, na Rádio Difusora em São Paulo, nomes da canção sertaneja como Tonico e Tinoco, não hesitou em atribuir a esse instrumento uma função mediadora no encontro entre as culturas portuguesa, africana e indígena, que teria assegurado a criação do caipira (Ferrete, 
I985). A violência contida no "verdadeiro abismo cultural entre mães e filhos" (Leonardi, I996: 25I) produzido pelo uso de instrumentos portugueses e canções religiosas, durante a catequese das crianças indígenas, e a impossibilidade de se produzir, de maneira efetiva, encontros em um sistema marcado pela escravidão, deveriam ser suficientes para desconsiderar pretensões excessivas e ilusórias de se chegar a um ponto original. Pode-se daí extrair muitas conclusões, incluída a de que, sem sertão ou caipiras, talvez a canção sertaneja não tivesse nunca existido. Não se trata aqui, entretanto, de desconstruir mitos nem afirmar que tudo não passa de "construção" intelectual. Há um Brasil sertanejo bastante real. Melhor, há vários Brasis sertanejos. A canção irá tratar de alguns deles e, entre tantos, este artigo, privilegiará o Brasil de I964 a I985, cantado por muitos compositores desse cancioneiro por meio de um olhar marcado pela ideia de esperança.

Um passo anterior foi necessário. Inverter a pergunta que orienta o debate em torno das definições sertanejo/caipira. Ou seja, em vez de determinar a forma-canção apropriada para o mundo rural, reconhecer o mundo rural narrado por essa forma-canção. Rural e urbano permanecem entrelaçados nesse cancioneiro de várias maneiras e são mutuamente dependentes. Assumir como positiva a diversidade dos personagens que compõem essas narrativas musicais - migrantes, boiadeiros, índios, garimpeiros, empresários rurais, peões de comitiva, caminhoneiros, lavradores, boias-frias, agentes de colonização - em vez de procurar um núcleo rural puro foi condição primeira para escapar de dicotomias estereotipadas e ao mesmo tempo identificar a força dos estereótipos que ecoa nessas canções. Os encontros e enfrentamentos desses personagens tiveram papel fundamental na configuração do Brasil rural e urbano que se seguiria ao fim do período militar. No cancioneiro sertanejo, essa confluência de interesses, instável e às vezes perigosa, é impulsionada por um ideal de esperança. Este mesmo afeto que irrompe contra o medo e se recusa à carência. Mas também aquela esperança lisonjeira, intencionalmente estimulada, em que, como nos lembra o filósofo Ernst Bloch (2006: I5) em O princípio esperança, "o futuro seria o letreiro luminoso do bar noturno anunciando a ausência de futuro".

Quando os intérpretes e compositores sertanejos cantaram as políticas agrárias executadas durante a ditadura militar, o fizeram pela perspectiva dos liberais conservadores de direita, mas também pela maioria de seus ouvintes, os trabalhadores rurais nas periferias ou nas roças. Nesse cancioneiro, a ligação entre essas perspectivas foi regulada pela manipulação de imagens objetivas de esperança (Bloch, 2005). Um novo tempo, um outro lugar, um Brasil do futuro inaugurado pelos militares. Foi o ideal de esperança que, nessas canções, convergiu diferentes concepções de reforma agrária em um impulso para a superação de um presente insatisfatório. Esse princípio ambíguo, capaz de provocar ilusões e firmar-se como o mais sério benefício para homens e mulheres, 
foi mobilizado no cancioneiro sertanejo para atribuir sentido a suas narrativas musicais sobre as transformações decorrentes da política agrária executada entre 1964 e 1985 .

\section{A GRANDE ESPERANÇA}

Em I965, quem sintonizasse a Rádio Nacional se surpreenderia com "A grande esperança”, interpretada por Zilo e Zalo. Composta por Francisco Lázaro e Goiá, essa foi uma das poucas canções sertanejas cuja referência aos personagens era realizada a partir da radicalização de um sentimento entre os homens do campo, de pertencimento a uma determinada categoria de trabalhadores: a classe. O sucesso da canção levou a gravadora a lançar um compacto no mercado internacional, e a dupla sertaneja acabou sendo a primeira a vender discos no exterior (Marcondes, 2000: I77). Diferente das toadas gravadas até então, cujas narrativas privilegiavam fatalidades individuais, como "Chico Mineiro", "Ferreirinha”, "Cabocla Tereza", "O menino da porteira”, entre tantas outras, com "A grande esperança", o sujeito passou a ser coletivo: a classe roceira. Essa passagem do individual para o coletivo, pela canção, expressa o momento em que a miséria e a violência no campo deixam de ser considerados traços de trajetórias particulares para ser definidas como problemas comuns a toda uma parcela da sociedade. Tal passagem teve início nos anos I950 e chegou ao ponto máximo na década seguinte com a defesa da reforma agrária pelos camponeses organizados na luta pela terra (Grynszpan, 2002). A identificação do trabalhador rural como categoria abre a canção de Zilo e Zalo:

A classe roceira e a classe operária

Ansiosas esperam a reforma agrária

Sabendo que ela dará solução

Para situação que está precária.

Os roceiros e o conjunto de trabalhadores urbanos, igualmente explorados, constituem o grupo dos indivíduos para quem a reforma agrária se afirma como demanda legítima. A utopia concreta, nos termos de Ernst Bloch. Em I965, a canção repercute o ajuste proposto em I962, durante o I Congresso Nacional dos Lavradores e Trabalhadores Agrícolas, para a realização de uma "reforma agrária, efetivamente democrática e progressista" (Stedile, 2005: 75). Nesse congresso, representantes e delegados das principais organizações camponesas do país, como a União dos Lavradores e Trabalhadores Agrícolas do Brasil (Ultab), o Movimento dos Agricultores Sem Terra (Master) e as Ligas Camponesas entregaram ao presidente João Goulart a Ia Proposta de Reforma Agrária Unitária dos Movimentos Camponeses do Brasil. O documento exigia a "radical transformação da atual estrutura agrária do país" (Stedile, 2005: 75) por meio da desapropriação dos latifúndios, a ser repassados a baixo custo para os trabalhadores, e 
da distribuição gratuita das terras devolutas. Essa alteração da situação agrária brasileira só seria possível com a organização das "massas trabalhadoras do campo, fraternalmente ajudadas em sua luta pelo proletariado das cidades, os estudantes, a intelectualidade e demais forças nacionalistas e democráticas do patriótico povo brasileiro" (Stedile, 2005: 75).

Que a estrutura agrária era um problema para a modernização do país parecia não haver dúvidas. Até mesmo liberais conservadores de direita identificavam a necessidade de enfrentar a questão, com o objetivo de promover o desenvolvimento do capitalismo no Brasil. Para esses setores, entretanto, reforma agrária significava industrialização da produção. A melhoria do padrão de vida dos trabalhadores rurais deveria ser considerada a partir da ampliação do acesso à educação e saúde no campo. Para as esquerdas, por sua vez, o acesso à terra era a demanda prioritária. Na proposta entregue a João Goulart, lavradores e trabalhadores agrícolas esclareciam que a reforma agrária pretendida "diverge e se opõe frontalmente, portanto, aos inúmeros projetos, indicações e preposições sobre as pretensas 'reformas', revisões agrárias e outras manobras [...]" (Stedile, 2005: 76). O documento sugeria, entre outras medidas, que as desapropriações deveriam começar nas regiões mais populosas e ocorrer sem a indenização justa e prévia, prevista pela Constituição. Em I965, Zilo e Zalo cantaram essa reforma:

Saindo projeto do chão brasileiro

De cada roceiro plantar sua área

Sei que na miséria ninguém viveria

E a produção já aumentaria

Quinhentos por cento até na pecuária!

O projeto, cantado pela dupla, recupera a proposta do presidente João Goulart de uma modernização do campo baseada na distribuição de terras e, portanto, numa alteração significativa da estrutura fundiária do país. Essa democratização do acesso à propriedade precederia qualquer outro tipo de incentivo ao desenvolvimento agropecuário. Pautava-se pela lógica da reforma nas estruturas socioeconômicas. A entrega de terras para cada roceiro formaria uma classe média agrícola, com produção voltada para o mercado interno e capacidade de consumo de bens manufaturados. Essa estratégia se baseava em um modelo econômico distributivista em que a divisão da renda ao longo do processo de desenvolvimento econômico fortaleceria o mercado nacional. O aumento da produção seria consequência direta da democratização do acesso à propriedade. Contrapunha-se ao modelo produtivista cujo pressuposto era a rápida acumulação de capital para posterior aumento da capacidade industrial do Brasil, ainda que o sacrifício fosse o preço a pagar, no presente, pelo progresso futuro do Brasil (Alves, 2005). Na concepção distributivista, por sua vez, 
o latifúndio era considerado o maior obstáculo ao desenvolvimento da agricultura não apenas pela extensão de terra concentrada em poucas mãos, mas devido às relações de domínio, expropriação e imposição de mando, vigentes nas relações sociais estruturadas no interior desse tipo de propriedade. A execução de uma reforma agrária comprometida com a redução das desigualdades estabeleceria a correlação justa entre esforço e ganho. Daria fim à longa fase de privação, como cantada por Zilo e Zalo, compartilhada pelo conjunto dos trabalhadores brasileiros:

Esta grande crise que há tempos surgiu

Maltrata o caboclo ferindo seu brio

Dentro de um país rico e altaneiro, Morrem brasileiro de fome e de frio.

Em nossas cidades ricas em imóveis

Milhões de automóveis já se produziu, Enquanto o coitado do pobre operário

Vive apertado ganhando salário,

Que sobe depois que tudo subiu!

Nosso lavrador que vive do chão

Só tem a metade da sua produção

Porque a semente que ele semeia

Tem que ser a meia com o seu patrão!

Em resistência à continuidade da situação de falta absoluta, descrita nesses versos, a espera da democratização da propriedade continuou a encorajar os homens na luta contra o presente insatisfatório que se oferecia à vista. Zilo e Zalo gravaram essa canção após o general Castelo Branco assinar a primeira lei de reforma agrária do Brasil, o Estatuto da Terra. O decreto aprovado considerou a necessidade de "promover a justa e adequada distribuição da propriedade" e "erradicar os males do minifúndio e do latifúndio" (Stedile, 2005: I 20). No entanto, o Estatuto da Terra comprometeu-se, em igual medida, com o desenvolvimento da empresa rural, de interesse da elite agrária, situada principalmente nos estados do Sudeste e Sul, como São Paulo, Minas Gerais e Paraná - região sobre a qual se formou e expandiu a canção sertaneja. Para os influentes produtores agropecuários, a modernização do campo viria por meio do incentivo estatal a essas empresas, com produção destinada à exportação. Mantiveram-se contrários a qualquer alteração da estrutura fundiária. Para impedir ações nesse sentido, esses homens defenderam vigorosamente a inviolabilidade da Constituição de I946, cujo Artigo I4I vinculava as desapropriações de terra à obrigatoriedade do pagamento prévio em dinheiro. Na prática, esse artigo inviabilizava a reforma agrária. As tentativas de João Goulart em alterá-lo foram consideradas ameaças à democracia. Em I964, Castelo Branco, 
com a prerrogativa atribuída por um governo de exceção, aboliu a obrigatoriedade do pagamento prévio em dinheiro. Para essa elite agrária, fez-se urgente retirar do Estatuto da Terra a "noção de latifúndio por dimensão e o fim do estatuto da desapropriação por interesse social” (Mendonça, 2006: 50). Seus membros pressionaram o governo para interromper as mudanças que alimentavam as expectativas dos trabalhadores rurais, como advertem Goiá e Francisco Lázaro, em "A grande esperança":

O nosso roceiro vive num dilema

E o problema não tem solução

Porque o ricaço que vive folgado

Acha que o projeto se for assinado,

Estará ferindo a Constituição!

Ao longo de I964, o Estatuto da Terra foi alterado I4 vezes até ser assinado pelo general Castelo Branco. Entre os itens modificados, prevaleceram os relacionados à distribuição de terras e apoio ao trabalhador rural (Mendonça, 20I0). A reescrita do texto original reforçava a tendência produtivista, menos preocupada com a formação de uma classe média agrária e interessada no desenvolvimento da agroindústria para exportação. A aposta na modernização da agricultura executada por meio de uma política agrícola favorável à produção em larga escala, à entrada de capital estrangeiro, ao fornecimento de créditos e subsídios pelo Estado se sobrepunha ao projeto de fortalecimento do mercado interno pela distribuição da terra.

Mas a canção de Goiá e Francisco Lázaro ainda fala, interpela, segue chamando, repleta de futuro. Retoma o convite feito pelo presidente João Goulart, em seu discurso no dia I 3 março de I 964 na Estação Central do Brasil, e toma para si a "linguagem de esperança, de quem busca inspirar confiança no futuro e tem a coragem de enfrentar, sem fraquezas, a dura realidade do presente" (Goulart, I964). Após a ditadura militar interromper um movimento direcionado para a construção de uma sociedade justa e, em seu lugar, instalar a concentração fundiária que reforçaria a desigualdade social no campo, a canção valeu-se dessa esperança na luta contra o medo. Ainda que tênue ao final, equilibrando-se entre uma forma de consolo alheia ao mundo e a certeza da possibilidade de transformação nesse mesmo mundo. Nessa última chave, ela foi capaz de reinserir, em seu presente, sonhos de uma vida melhor entre os trabalhadores rurais. Insistem Zilo e Zalo:

Mas grande esperança o povo conduz

E pede a Jesus pela oração,

Pra guiar o pobre por onde ele trilha,

E para a família não faltar o pão. 
Eles aguardam a reparação das desigualdades para salvação do mundo por meio de mudanças nesse mesmo mundo por um "ato de esperar [que] não [se] resigna: ele é apaixonado pelo êxito no lugar do fracasso" (Bloch, 2005: 13) A ausência da esperança é de tal forma insuportável que, como lembra Ernst Bloch (2005: I5), "até mesmo a fraude, para que seja eficaz, tem de trabalhar com a esperança lisonjeira e perversamente estimulada”. Alertam Zilo e Zalo:

Que eles não deixam o capitalismo

Levar ao abismo a nossa nação,

A desigualdade aqui é tamanha

Enquanto o ricaço não sabe o que ganha

O pobre do pobre vive de ilusão!!

A opção pelo "capitalismo", foi compreendida pelos compositores como a escolha por um sistema contrário à instalação de cada roceiro em sua terra e, por consequência, responsável pelo aumento das desigualdades. A dimensão distributiva que ainda se manteve no texto final do Estatuto da Terra, apesar das constantes reescritas, limitou-se basicamente a dois pontos: os projetos de colonização, que fariam chegar ao homem sem-terra a terra sem homens, e a formulação de uma legislação social direcionada para o campo. A esperança manteve-se. O mesmo não se pode afirmar quanto ao objeto dessa espera.

\section{AVANÇAR SEM MUDAR}

Para a elite agrária, a modernização deveria instalar-se sobre o latifúndio e pela produção mecanizada, subsidiada pelo Estado. Essa é a contraproposta à divisão da terra demandada em "A grande esperança", oferecida pela canção "Se o governo me ajudasse", gravada em I965, por Jacó e Jacozinho. O mote construído pelos compositores Moacyr e Lourival dos Santos sintetiza a demanda dessa elite pelo apoio do Estado a seu projeto de modernização agrária. Replicando um discurso caro aos ruralistas, principalmente aqueles organizados na Sociedade Rural Brasileira (SRB) (Mendonça, 2010), cuja base de associados era essencialmente paulista, a dupla afirmou a falta de apoio público aos setores agropecuários:

Cultivei a terra bruta

Só na base de animais

Eu não pude fazer muito

Só fiz o que fui capaz

Se o governo me ajudasse

Eu fazia muito mais.

Os compositores exaltavam a iniciativa privada desses homens a quem atribuem um histórico comprometido com o desbravamento e a integração de 
terras incultas às áreas produtoras. O narrador toma para si a função do colonizador como argumento favorável à concessão de subsídios para seu projeto de ocupação do interior e reconquista dos sertões cujo povoamento, no século XVII, coube a personagens como Fernão Dias e Raposo Tavares - os bandeirantes paulistas. Ao assumir, na década de I960, a herança desses antepassados, os herdeiros economicamente empreendedores desses colonos aventureiros estariam aptos a promover o desenvolvimento econômico do país. O suporte do Estado na expansão dessa sociedade desbravadora, baseada em São Paulo, colocaria a autoafirmada habilidade paulista a serviço do progresso nacional. Em "Se o governo me ajudasse", a estratégia narrativa utilizada pelos compositores foi enumerar as possibilidades produtivas decorrentes da expansão de uma classe social já existente. Uma parcela da população disposta a deixar os centros urbanos para, como no passado, dirigir o processo de reconquista do campo. Cantam Jacó e Jacozinho:
Abandonei a cidade
Não quero voltar pra trás
Enfrentei o meu sertão
Derrubando os matagais
Se o governo me ajudasse
Eu fazia muito mais.

A mecanização da agricultura se impõe sobre qualquer demanda por terra. Em nenhuma estrofe da canção o desenvolvimento do país é associado à democratização da propriedade, como reivindicado pelos movimentos sociais no período anterior ao golpe. O olhar lançado pelos compositores sobre as regiões Norte e Centro-Oeste as ressignifica como sertão, ou seja, lugar de atraso e barbárie a ser superado por um processo modernizador capaz de acertar o ritmo dessa região ao dos estados industrializados, em particular, São Paulo. Os ruralistas atribuíam o atraso da agricultura ao maior interesse do governo pelo desenvolvimento urbano e consequente descaso com o incentivo à produção rural. Com o propósito de modernizar o campo brasileiro, os novos conquistadores na canção, como os bandeirantes no século XVII, se apossam de suas descobertas moldando a região e seus antigos habitantes de acordo com seus interesses. Terra havia rica e cheia de minerais, "o que falta no sertão é homem e materiais", afirmam os compositores. Em concordância com o "paulistocentrismo" divulgado nos discursos da SRB, em aliança com as demais entidades patronais regionais sob sua área de influência, a solução seria fazer do Brasil uma grande São Paulo. Cantam Davi e Durval, em "Se o governo me ajudasse": 
Pro Brasil não ter miséria

E aumentar o seu cartaz

É só expandir São Paulo

Mato Grosso e Goiás

Amazonas e Paraná

E também Minas Gerais

Sem apoio do governo

Eu fiz o que ninguém faz

Se o governo me ajudasse

Eu fazia muito mais.

A crença apaixonada em uma época de transformações radicais foi apropriada por Tião Carreiro e Pardinho, em "Tempo de avanço", composta por Lourival dos Santos e Tião Carreiro, em I969. Essa canção destacou dois importantes pontos referentes à questão agrária, em pauta no final dos anos I960. Um deles diz respeito à chegada ao poder do general Costa e Silva. Se em março de I964, o golpe militar representou a vitória do latifúndio agroexportador, ao final desse ano, a aprovação do Estatuto da Terra foi considerada pelo patronato rural novo retrocesso, e o general Castelo Branco, por sua vez, ao aprová-lo, passou a ser visto com desconfiança pelos produtores contrários a qualquer concessão no direito à propriedade.

Com o general Costa e Silva, o projeto agrário da elite agroexportadora, localizada principalmente no Sul e Sudeste do país, seria finalmente colocado em prática. De fato, foi a partir de ig68 que a transformação do setor agrário ocupou a pauta econômica do Estado militar. Os incentivos à agricultura seguiram as demandas específicas a cada região do país. Para o Sul, seriam concedidos benefícios à agroindústria; para o Norte e Centro-Oeste, a incorporação de novas terras para o cultivo; para o Nordeste, os investimentos seriam na dinamização da indústria açucareira (Houtzager, 2004). Inaugurava-se o tempo de avanço, como cantado por Tião Carreiro e Pardinho. Estruturada em rimas organizadas pela justaposição de termos opostos, como num desafio, a canção narra o estabelecimento desse tempo de avanço como sendo a inauguração de um período de transformação no qual as injustiças seriam reparadas e as vinganças executadas. No ano em que o AI-5, decretado em dezembro de ig68, foi largamente mobilizado na repressão a qualquer forma de contestação do regime militar, cantam Tião Carreiro e Pardinho:

Vou soltar o inocente não tem culpa quem prendeu

Vou castigar quem matou, vou rezar para quem morreu

Vou defender quem apanha, batendo em que bateu

Vou tomar de quem roubou, tirando o que não é seu [...]. 
Esse período de mudanças foi caracterizado pelos compositores como uma época propícia para execução de vinganças e instalação do arbítrio por quem se colocava acima das instituições democráticas e dos direitos civis. Uma fala próxima à defendida por latifundiários, para quem o uso da violência garantiu o avanço econômico que seria responsável pela transformação social e econômica do campo. Além disso, deu fim à influência das organizações de esquerda no campo, que atribuíam à revolução a capacidade de instaurar uma estrutura social e política justa e cujo primeiro passo para sua execução caberia aos camponeses.

A concepção de uma transformação social dirigida pelo camponês estaria no centro da canção "Disparada", de Geraldo Vandré e Theo de Barros, interpretada por Jair Rodrigues, Trio Maraiá e Trio Novo, em I966, durante o II Festival da Música Popular Brasileira, da TV Record. Em “Tempo de avanço”, como em "Disparada", essa renovação social também começaria no campo, mas se daria via o progresso/avanço. A construção de um novo lugar não mais se coloca como consequência do despertar para ação, a ser vivenciado pelo narrador/boiadeiro, interpretado por Jair Rodrigues. Se o narrador de Lourival dos Santos e Tião Carreiro é um enviado do sertão (O destino aqui me trouxe/Cantar para você eu vou/Eu só trouxe coisa boa/Foi meu sertão que mandou) o boiadeiro cantador de Geraldo Vandré, por sua vez, também vem lá do sertão. Eles compartilham o ponto de partida, mas cada um propõe um modo específico para estabelecer as bases de sustentação da sociedade, a ser recriada a partir desse ponto. Vandré e Théo de Barros apostam na ação transformadora dos homens do campo; Lourival dos Santos e Tião Carreiro, na ação do progresso para correção do mundo. Enquanto o mundo muda, quem puder que se segure, cantam Tião Carreiro e Pardinho:

A terra hoje balança vou aguentar o balanço

Quem espera sempre alcança eu espero e não me canso

Cantando a gente avança para depois ter descanso

Cheguei trazendo esperança, cantando em tempo de avanço.

Esses versos funcionam como refrão e separam a primeira e a segunda parte da canção. Eles introduzem o segundo ponto importante abordado pela canção sertaneja com relação ao projeto agrário que começava a ser executado no final dos anos I960. Trata-se do jogo, narrado pela canção caipira, entre sustentar a permanência da esperança e alterar o objeto a ser esperado: o progresso/avanço em vez da terra. Com essa mudança, a espera faz-se resignada em concordância com um modelo econômico produtivista, preocupado em "acumular suficiente capital para promover a 'arrancada' do desenvolvimento econômico" (Alves, 2005: I77). Uma lógica popularizada pela imagem do bolo que cresce primeiro para ser depois dividido ou, como diria Tião Carreiro e Pardinho, avançar primeiro, descansar depois. 
Com o golpe militar, a transformação agrária radical derivada do desenvolvimento econômico se sobrepôs às demandas por terra dos lavradores organizados, no início dos anos I960. O som do chicote trazido à cena pela interpretação de Jair Rodrigues durante o II Festival da Música Popular Brasileira, em I966, por uma queixada de burro, fazendo as vezes de percussão, foi inserido na gravação de Tião Carreiro e Pardinho, através de efeito sonoro similar executado durante o refrão. Em "Disparada", o som sinalizou a violência em potencial que acompanharia a tomada de consciência dos trabalhadores no campo. Citado por Tião Carreiro e Pardinho, evocou a violência latente que acompanharia qualquer resistência à espera das transformações anunciadas nesse tempo de avanço.

Grande parte do cancioneiro sertanejo, ao tematizar as políticas agrárias, principalmente entre I967 e I976, assumiu o progresso como objeto da espera dos trabalhadores rurais. Assumiu, também, a concessão de direitos sociais pelo governo militar. Em maio de I97 I, o general Emílio Garrastazu Médici anunciou o Programa de Assistência ao Trabalhador Rural (Prorural) a ser executado pelo Fundo de Assistência ao Trabalhador Rural (Funrural), uma autarquia ligada ao Ministério do Trabalho e Previdência Social, responsável por garantir ao homem do campo a aposentadoria por velhice e invalidez, pensão, auxílio-funeral, serviços de saúde e social. Os direitos legalmente estipulados pelo Estatuto do Trabalhador Rural, instituído durante o governo do presidente João Goulart, e pelo Estatuto da Terra foram apropriados como benefícios concedidos pelos militares. O cancioneiro caipira reverberou essa ideia. No ano em que o Prorural foi lançado, a dupla Davi e Durval gravou a canção "Lei Agrária":
A Lei Agrária que por nós era esperada
Foi agora assinada pelo chefe da nação
E na doença, vem a lei da previdência
Você também vai ter assistência e também sua pensão
Irmão do campo, brindo aqui o seu sucesso!
Viva o Brasil-Progresso! Viva a revolução!

Assim como "A grande esperança”, essa canção foi composta por Goiá e Francisco Lázaro e, em I974, interpretada por Zilo e Zalo. "Lei agrária" e "A grande esperança” possuem uma importante relação de continuidade. O diálogo entre ambas possibilita identificar a assimilação da ideia de uma reforma agrária como concessão de direitos sociais. Em um intervalo de nove anos, a "lei agrária" passou a ocupar o lugar da "reforma agrária". A necessidade de "cada roceiro ganhar sua área" é preterida pela concessão da "lei da previdência, [...] assistência e [...] pensão". O risco maior dessa passagem foi ter dado fim à espera, como indicado no primeiro verso, ou melhor, ao movimento capaz de impulsionar a ação transformadora, impedir a resignação e instigar a luta con- 
tra o presente insatisfatório. Com ela, vai-se o conflito, como conclui a última estrofe da canção:

Coisas sublimes acontecem nessa terra

Onde a paz venceu a guerra e o bem ganhou do mal

Como me orgulho de você Brasil querido

O exemplo a ser seguido para a paz universal.

A canção expõe talvez como nenhuma outra, a relação entre legislação agrária e desmobilização política no campo. Diferente do ocorrido em I965, dessa vez, o olhar dos compositores compartilha o otimismo dos grandes produtores rurais (e não dos trabalhadores rurais). Essa passagem do direito à terra ao direito à saúde e educação alinha-se às propostas de inclusão do trabalhador rural divulgadas pelas principais entidades patronais. A importância histórica dessa canção está em sua capacidade de transmitir e expor o artifício que possibilitou a despolitização da questão agrária pelos governos militares. Durante o intervalo entre a gravação de "A grande esperança" e a de "Lei agrária", a concessão de direitos sociais ocupou o lugar da conquista da terra como objeto da espera dos trabalhadores rurais. O custo da expansão desses direitos, por sua vez, não recaiu sobre o dono da terra. Foi reunido com a cobrança de impostos sobre produtos rurais e sobre a folha de pagamento de empresas urbanas. Todos eles devidamente repassados ao consumidor (Carvalho, 200I: I7I).

\section{AMAZÔNIA: UM LUGAR PARA A ESPERANÇA}

A concessão de benefícios foi um dos eixos da política adotada, principalmente após I968, para reduzir a tensão em torno da questão agrária. O outro eixo tinha como objetivo conter a espera pela posse da terra. Para isso, os militares retomaram os projetos de colonização, uma fórmula para desmobilizar as organizações de trabalhadores rurais, desde os governos de Getúlio Vargas e Juscelino Kubitschek. Essa estratégia se resumiu ao dístico: "fazer chegar ao homem sem-terra a terra sem homens". A Amazônia era essa terra. A Transamazônica, o caminho para se chegar a ela ou, como afirmariam Tonico e Tonico, a estrada que transportaria a esperança.

Em I97 I, a dupla gravou a canção "Transamazônica", composta em parceria com José Caetano Erba. O título reverenciava a obra-síntese do Plano de Integração Nacional (PIN), anunciado pelo general Emílio Garrastazu Médici, em junho de i970. A estrada faria a junção entre as áreas de tensão social derivada da luta pela terra e a recém-delimitada Amazônia Legal. Se a mecanização da produção e a legislação social foram definidas pelas políticas agrárias dos governos militares como objeto da espera dos trabalhadores rurais, a Amazônia seria a localização geográfica dessa esperança e passou a orientar a eterna procura desses homens por uma espécie de paraíso na terra. As quadras da 
canção "Transamazônica", de Tonico e Tinoco, interpostas por um refrão, extraíram elementos da realidade e exibiram a complexidade dos interesses direcionados àquela região. Nessa capacidade reside a força dessa canção.

Por um lado, suas quadras assimilaram a perspectiva projetada sobre a Amazônia pelos homens de negócio do período. A partir desse ponto de vista, a natureza foi apresentada como um todo homogêneo, em que diversidade e conflito submergem nos limites de um verde indiviso. Os muitos trabalhadores que para lá se dirigiram são inseridos nessa floresta por meio do refrão. Ele introduz a voz dos muitos homens que se dispuseram a partir. Cantam Tonico e Tinoco, ao fim de cada quadra:

\section{Ai, Sá Dona, \\ Nós vamos pro Amazonas.}

A apresentação de um espaço uniforme e indiferenciado abre a canção "Transamazônica". Do alto, as copas das árvores da floresta embaralham-se e dissimulam a diversidade sob a preponderância de um único elemento: o verde. Formam a paisagem do vazio, em busca do qual homens de negócio partem à procura. Na primeira quadra, cantam Tonico e Tinoco:

O grande tapete verde,

O teu mundo encoberto

A estrada Transamazônica

Trouxe você bem mais perto.

Nesse tapete, a prevalência do verde mantém coesa qualquer dispersão ou desarmonia. Nele o doentio, o selvagem, destoante, submergem. Mas, para se apropriar desse espaço, antes é preciso alcançá-lo. A estrada Transamazônica revelaria o desconhecido e abriria a floresta ao conquistador. A estrada é o único corte produzido sobre esse verde. Situa o espaço místico, isolado, desconhecido e refratário à modernização ao alcance desse conquistador e o coloca próximo das regiões em que predomina uma cultura técnico-científica. Quanto mais obscuro e inacessível ele se fizer, tanto mais grandiosas e irrestritas são concebidas as ações para domá-lo. A estrada Transamazônica resume o conjunto dessas ações.

Passagem aberta para os homens do campo chegarem ao bom lugar. Com esse objetivo, a homogeneidade desse espaço é, então, forçada pela estrada que permitirá a uma população selecionada entre sem-terras, sitiantes e retirantes da seca, disposta a desgarrar-se, enfrentar o desconhecido e fracionar essa uniformidade, alcançá-lo. O refrão da canção de Tonico e Tinoco soube fixar no tempo a voz dessa gente que, em I97 I, permanecia como a imagem fixada por Euclides da Cunha (I976: I07), entre I904 e I905, durante sua ida à Amazônia: "Perpetuamen- 
te a mudarem de sítio". Ao fim da interpretação da primeira quadra, a canção introduz o movimento à procura do milagre. Novamente, cantam Tonico e Tinoco:

Ai, Sá Dona,

Nós vamos pro Amazonas.

Após o refrão, a segunda quadra da canção "Transamazônica” insere um importante desdobramento desse movimento: a urbanização da região. O governo militar prometeu a cada migrante o título da propriedade, um lote urbano com casa, galinheiro, eletricidade, água encanada e dinheiro para as despesas dos primeiros 6 a I 2 meses. Tonico e Tinoco, sem cerimônias, esboçaram sobre a área transformações que poderiam vir com a instalação da Transamazônica e dos núcleos de colonização às margens dessa e das demais rodovias federais projetadas para a região. Nesse segundo momento, os compositores pontuam a amplidão indivisa do tapete verde com núcleos de povoamento:

Mais um povoado que cresce

Naquela mata esquecida

Novo horizonte aparece

No fim da estrada comprida.

A coesão de pessoas em direção ao Norte do país é reforçada pela utilização de um coral de vozes na interpretação desse trecho. Ele substitui o dueto em terças de Tonico e Tinoco, e estabelece a diferenciação entre o discurso construído sobre esse território e sua repercussão junto à população, ou seja, a afluência de migrantes aos núcleos coloniais. Com o jogo narrativo estabelecido por essa alternância, a canção captura a ambiguidade da política agrária estabelecida durante o governo Médici. Uma política capaz de plantar no coração de centenas de trabalhadores rurais sem terra a esperança em adquirir, além de uma propriedade, máquinas, sementes e acesso a serviços sociais de primeira necessidade. E, ainda mais, capaz de federalizar grandes parcelas do território brasileiro para repassá-las ao capital privado com o objetivo de defender áreas de fronteira, explorar a região e desenvolver a produção para o mercado externo, por meio da instalação de empresas agropecuárias e de colonização. Para Tonico e Tinoco, a Transamazônica acomodaria esforço, sacrifício, progresso e, portanto, as bases sobre a quais militares e empresários rurais procuravam assentar a esperança dos homens que permaneciam sem terra. Cantam Tonico e Tinoco:

Um governo trabalhando, O nosso Brasil que avança, A estrada Transamazônica, Transporta nossa esperança. 
A imagem da exuberância da natureza e a visão das grandes extensões de terras divulgadas pelas agências de colonização foram logo confrontadas, pelos colonos, com a realidade do solo arenoso, das rodovias não asfaltadas, das longas distâncias entre os lotes agrícolas e as agrovilas, do desmatamento na base do machado, dos acidentes com o manejo da motosserra, do endividamento, do atraso na chegada do adubo, da malária, da ausência de serviços médicos, do alto preço dos alimentos, enfim, com a sensação de abandono. Muitos tomaram o caminho de volta. O destino desses trabalhadores era incerto. Alguns arriscaram a sorte no garimpo, outros trabalharam como diaristas nas grandes empresas. Poucos reaviam suas propriedades nos lugares de origem. Aqueles que não conseguiam estavam fadados a "errar ao acaso e arranjar-se com biscate e outros serviços provisórios" (Santos, I993: I84).

Em I980, a canção "Êta país da América", composta e interpretada por Rolando Boldrin, narrou a errância desesperada dos trabalhadores rurais que, na década de I970, partiram para a Amazônia em direção à terra da promissão e de lá voltaram, no início dos anos I980, sob o estigma do fracasso. Muitos deles venderam seus sítios no sul do país, antes de partir, e por não produzir o suficiente para quitar os empréstimos bancários contratados para compra da propriedade, das máquinas e fertilizantes, não conseguiram se sustentar nas novas terras.

A falta de estrutura nas colônias agrícolas e a crise na produção, pelo desconhecimento desses trabalhadores sobre a melhor forma de aproveitamento do solo, aumentavam a inadimplência, e, ainda assim, dia a dia chegavam novos migrantes em busca de seu lote. Isso trouxe como consequência a falência do projeto, atribuída pelas agências de colonização à incapacidade individual dos pioneiros. Foram tachados por muitos desses agentes como preguiçosos, vagabundos e malandros incapazes de tirar proveito das vantagens oferecidas pelos programas. Sem perspectivas, obrigados a lidar com o fim do sonho, ainda enfrentaram "o desprezo de alguns vizinhos que permaneceram, o desdém das autoridades locais, de alguma forma inquietas vendo populações excedentes voltarem ao local, a desaprovação do aparelho estatal que lhe proíbe requerer de novo um lote de terra" (Santos, I993: I86). Sobre esses homens, canta Rolando Boldrin:

Eu vim lá dos cafundós do Judas

E as mudas de lugar foi pra eu melhorar de vida

Mas que vida, que vida

Que vida vou levar, só Deus sabe

Velhas estradas das milongas coloridas

Grandes atalhos dão num beco sem saída

Se eu vim do norte ou lá do sul pouco importará

Leste ou oeste é um faroeste pra poder chegar. 
$\mathrm{Na}$ construção da saga desses personagens errantes, o compositor retomou a figura do Jeca Tatu, composta por Monteiro Lobato, em I9I4, e inseriu-a em meio ao Éden-Eldorado que, na década de i970, foi situado na floresta amazônica. No instante mesmo em que a exuberância e o mistério desse lugar desapareciam ante os interesses econômicos, os militares procuravam replantá-la, com o apoio da iniciativa privada, na imaginação dos brasileiros como o verdadeiro cenário nacional. A opulência da floresta corresponderia ao ideal de grandeza para o país, perseguido por esses homens, desde I964, e caberia a eles a força necessária para domá-la. Em I980, passados dez anos do lançamento do Plano de Integração Nacional (PIN), Rolando Boldrin redirecionou da Amazônia para o Jeca Tatu o ponto de sustentação do país e, com isso, subverteu a relação colaborativa estabelecida entre a Amazônia Legal e os homens nela imersos. Afirma o cantor e compositor:

Êta país amazônico
Harmônico e azul
É um país biotônico
Do Jeca, do Jeca-Tatu.

No início da década de I980, em Brasil Novo, a agrópole próxima a Altamira, que, em I972, recebeu o general Médici para a inauguração do primeiro trecho da rodovia Transamazônica, quase não havia moradores. Segundo depoimento: só ficou quem teve perseverança. Foi na passagem do Brasil biônico, dos prefeitos, senadores e governadores indicados aos cargos pelos generais ou eleitos pelo voto indireto, para o Brasil biotônico, dos Jecas Tatus - uma referência ao Biotônico Fontoura, fortificante consumido principalmente entre os trabalhadores rurais, cujo laboratório publicou as histórias em quadrinhos do Jeca Tatuzinho -, que o compositor ostentou a permanência de um Brasil descrito por Lobato, em I 9I4. Um lugar em que, "no meio da natureza brasílica, tão rica de formas e cores", só o caboclo "não fala, não canta, não ri, não ama. Só ele no meio de tanta vida não vive" (Lobato, I97I).

Enquanto os interesses econômicos das elites agrárias, contemplados por subsídios disponibilizados pelo governo militar, rapidamente transformavam a natureza e as técnicas de trabalho conhecidas por toda uma geração de artistas sertanejos, suas composições registravam a velocidade com a qual essas transições se davam. Devido à rapidez dessas mudanças, muitas vezes elas não foram absorvidas pelos artistas, mesmo aqueles cujo repertório contemplava exaltações ao avanço promovido pelos militares. Os irmãos Vieira e Vieirinha, em I984, ao fim da ditadura militar, gravaram "Meu sertão acabou", de Orlando Martins e Vieira. A força narrativa da paisagem desenhada pelos compositores nessa canção está em sua capacidade de agregar, em um mesmo enquadramento, elementos da vida cotidiana e significá-los como índices das 
profundas alterações promovidas pela política agrícola militar, ao fim do governo discricionário. Cantam Vieira e Vieirinha:

Fui rever a minha terra, com grande satisfação

Que triste desilusão, já não era mais a mesma

Meu Deus que transformação [...]

Não vi mais a cachoeira, que era uma coisa rara

Porque já foi represado pelo rio [sic]

$\mathrm{Na}$ estação da cidade trem de ferro já nem passa

Não vi mais os cafezais, a lavoura foi cortada

No meio das invernadas, sobrou um monte de coivara [...]

Não vi os canaviais, também não vi a moenda

O carro silenciou, não geme mais o cocão

Apenas ficou o peão para tomar conta da fazenda

As colônias estão vazias, já não mora mais ninguém

Aonde era lavoura, hoje só boiada tem.

Um desses índices é a referência ao desaparecimento da cachoeira. O represamento dos rios para a construção de hidrelétricas, como Itaipu (PR) e Tucuruí (PA), levou à expulsão dos moradores das regiões a ser alagadas. No Paraná, muitos desalojados foram transferidos para a colônia Pedro Peixoto, no Acre. Entre todas as alterações provocadas na paisagem, pelas hidrelétricas, estava o desaparecimento das Sete Quedas, uma das cachoeiras com maior volume de água do mundo que, em I982, foi incorporada ao lago de Itaipu.

Outro índice mobilizado pelos compositores foi a retirada de quilômetros de malhas ferroviárias e a desativação das plataformas de embarque e desembarque em todo o país. O avesso do grande Brasil rodoviário, mobilizado na canção, são as cidades fantasmas surgidas em diversas regiões brasileiras ao redor das estações vazias. A construção de uma malha viária tornou obsoletos os tradicionais meios de transporte de mercadorias, quando não melancólicos.

Outro elemento inserido na canção foi a derrocada dos canaviais ligados à moenda e a convergência do olhar para a usina. Ao seu redor, organizaram-se cidades-dormitórios, periferias e um espaço vazio de gente, preenchido apenas pelo verde sem fim dos canaviais. Nele, não cabiam mais as roças, parceiros, colonos ou arrendatários. Sob a monotonia da monocultura, firmava-se o "desaparecimento da paisagem e do habitat da civilização cafeeira" (Silva, I999: 22 I). As grandes áreas verdes substituíram as casas esparsas dos antigos moradores e a diversidade do cultivo para a subsistência (Silva, I999: 22 I). O fim do regime de colonato e a despersonalização do fazendeiro paternal pela inserção da ausente figura do dono da terra, sem vínculo com sua propriedade, deixando-a aos cuidados de um peão designado. Por fim, a supremacia da pecuária sobre as demais atividades agrícolas. No enquadramento de uma fazen- 
da, Vieira e Vierinha souberam registrar os efeitos do progresso, do qual eles próprios saíram em defesa, para concluir, em seguida:

Os homens dono da terra

Fazem só o que lhes convém

Por causa da ambição

Meu sertão morreu aos poucos

Coração desse caboclo

Com ele morreu também.

O fim do sertão, como decretado por Vieira e Vieirinha ao término da ditadura militar, é simultâneo à ascensão de uma nova elite agrária e com ela das novas relações sociais e políticas no campo. É o fim do paternalismo exercido pelos grandes fazendeiros acompanhado de um violento processo de proletarização dos trabalhadores rurais. A velocidade das transformações impostas por uma modernização autoritária e excludente atribuiu contornos fantasmagóricos a essa população que, por séculos, manteve seu cotidiano inalterado: acender o fogo, esquentar a água, tirar o leite, lidar na roça, encher os potes, aguar a horta, curar-se na benzedeira, rezar o terço, cortar a lenha, conversar sob os lampiões, banhar-se no rio.

Em “Peão", canção de Almir Sater e Renato Teixeira, gravada em I988, toda essa vida é situada sob a aura do abandono, das vidas suspensas, do extinto que teima em permanecer para iluminar, com uma luz espectral, todo um modo de vida abortado e para o qual não há mais retorno. Na interpretação de Almir Sater:

Ventos que arrombam janelas

E arrancam porteiras

Espora de prata riscando as fronteiras

Selei meu cavalo

Matula no fardo

Andando ligeiro

Um abraço apertado

E um suspiro dobrado

Não tem mais sertão.

O avanço das técnicas agrícolas, das estradas, do caminhão e a proliferação de núcleos urbanos lançaram os antigos habitantes desse sertão em um mundo onde suas vivências não mais cabiam. Almir Sater e Renato Teixeira, com fina sensibilidade, souberam perceber o vagar dessa gente que permanecia em busca de uma ligação com o lugar do qual foram lançados, incapazes de perceber que não mais se tratava de um espaço. Havia passado de um lugar 
determinado a um tempo pretérito e, portanto, só acessível à recordação, ou seja, ao coração. Canta Almir Sater:

Os caminhos mudam com o tempo

Só o tempo muda um coração

Segue seu destino boiadeiro

Que a boiada foi no caminhão

A fogueira, a noite

Redes no galpão

O paiero, a moda,

O mate, a prosa

A saga, a sina

O causo e onça

Tem mais não

Ô peão.

Recebido em 3I/I/20I8 | Revisto em I7/I2/20I8 | Aprovado em 2I/I/20I9

Marcela Elian Lima é doutora em história pela

Universidade Federal de Minas Gerais (UFMG) e pesquisadora do Projeto República: Núcleo de Pesquisa, Documentação e Memória/UFMG desde 2003. 


\section{REFERÊNCIAS BIBLIOGRÁFICAS}

Alonso, Gustavo. (2015). Cowboys do asfalto: música sertaneja e modernização brasileira. Rio de Janeiro: Civilização Brasileira.

Alves, M. Helena M. (2005). Estado e oposição no Brasil (I964I984). São Paulo: Edusc.

Bloch, Ernst. (2005). O princípio esperança, v. I. Rio de Janeiro: UERJ/Contraponto.

Caldas, Waldenyr. (1977). Acorde na aurora: música sertaneja e indústria cultural. São Paulo: Ed. Nacional.

Carvalho, José Murilo. (200I). Cidadania no Brasil: o longo caminho. Rio de Janeiro: Civilização Brasileira.

Cunha, Euclides da. (I976). Um paraíso perdido: reunião dos ensaios amazônicos. Petrópolis/Brasília: Vozes/INL.

Dent, Alexander Sebastian. (2009). River of tears: country music, memory and modernity in Brasil. Durham: Duke University Press.

Ferrete, José L. (1985). Capitão Furtado: viola caipira ou sertaneja? Rio de Janeiro: Funarte.

Goulart, João. (1964). Discurso na Estação Central do Brasil. Disponível em <http://memorialdademocracia.com. br/card/comicio-da-central-300-mil-apoiam-reformas/ docset/ı060>. Acesso em I5 jun. 2018.

Grynszpan, Mário. (2002). Da barbárie à terra prometida. In: A república no Brasil. Rio de Janeiro: Nova Fronteira/ FGV, II6-I55.

Houtzager, Peter P. (2004). Os últimos cidadãos: conflito e modernização no Brasil rural (I964-I995). São Paulo: Globo. Leonardi, Victor. (I996). Entre árvores e esquecimentos: história social nos sertões do Brasil. Brasília: Ed. Unb/Paralelo I5.

Lobato, Monteiro. (I97I). Urupês, São Paulo: Brasiliense.

Marcondes, Marcos. (2000). Enciclopédia da Música Brasileira: sertaneja. São Paulo: Art Editora/Publifolha.

Martins, José de Souza. (I975). Capitalismo e tradicionalismo: estudos sobre as contradições da sociedade agrária no Brasil. São Paulo: Pioneira.

Mendonça, Sônia R. (20I0). O patronato rural no Brasil recente (I964-I993). Rio de Janeiro: UFRJ. 
Mendonça, Sônia R. (2006). A questão agrária no Brasil: a classe dominante agrária - natureza e comportamento (I964I990). São Paulo: Expressão Popular.

Nepomuceno, Rosa. (I999). Música caipira: da roça ao rodeio. São Paulo: 34 .

Oliveira, Alan de Paula. (2009). Miguilim foi pra cidade ser cantor: uma antropologia da música sertaneja. Tese de Doutorado. PPGAS/Universidade Federal de Santa Catarina. Sant'Anna, Romildo. (2000). A moda é viola: ensaio do cantar caipira. São Paulo/Marília: Arte \& Ciência/Unimar.

Santos, José Vicente Tavares dos. (1993). Matuchos: exclusão e luta. Do sul para a Amazônia. Petrópolis: Vozes.

Silva, Maria Aparecida de Moraes. (I999). Errantes do fim do século. São Paulo: Unesp.

Sousa, Walter de. (2005). Moda inviolada: uma história da música caipira. São Paulo: Quiron.

Stedile, João Pedro (org.). (2005). A questão agrária no Brasil. Programas de Reforma Agrária (1946-2003), v. 3. São Paulo: Expressão Popular.

Tinhorão, José Ramos. (200I). Cultura popular: temas e questões. São Paulo: Ed. 34.

Vicente, Eduardo. (2010). Chantecler: uma gravadora popular paulista. Revista USP, 87, p. 74-85.

Vilela, Ivan. (2013). Cantando a própria história: música caipira e enraizamento. São Paulo: Edusp. 


\section{A GRANDE ESPERANÇA: POLÍTICA AGRÁRIA NA CANÇÃO SERTANEJA DURANTE A DITADURA MILITAR (1964-1985) \\ Resumo}

$\mathrm{O}$ artigo tem como objetivo analisar, no cancioneiro sertanejo produzido entre I964 e I985, imagens objetivas de esperança produzidas por seus compositores a partir das políticas agrárias executadas durante a ditadura militar. Ao compor essas imagens, o fizeram pela perspectiva dos liberais conservadores de direita, mas também pela maioria de seus ouvintes, os trabalhadores nas periferias ou nas roças. É a esperança que, nessas canções, convergiu diferentes concepções de reforma agrária em um impulso para a superação de um presente insatisfatório. Esse princípio ambíguo, capaz de provocar ilusões e firmar-se como o mais sério benefício para homens e mulheres, foi mobilizado no cancioneiro sertanejo para atribuir sentido a suas narrativas musicais sobre as transformações decorrentes da política agrária executada nesse período.

\section{THE GREAT HOPE: AGRARIAN POLICY IN THE SERTANEJO SONG REPERTOIRE DURING THE MILITARY DICTATORSHIP (1964-1985)}

The article's objective is to analyse, in the Sertanejo song repertoire produced between I 964 and I985, objective images of hope produced by their composers in response to the agrarian policies implemented during the military dictatorship. In composing these images, they did so from the perspective of right-wing liberal conservatives, but also from that of the vast majority of their listeners, workers on the urban peripheries and in rural areas. It is hope that, in these songs, combined different conceptions of agrarian reform in a drive towards overcoming a dissatisfactory present. This ambiguous principle, capable of both provoking illusions and becoming realized as a serious benefit to men and women, it was mobilized in the Sertanejo song repertoire to give meaning to its musical narratives on the transformations arising from the agrarian policy pursued during this period.

\section{Palavras-chave}

Agroindústria; esperança; canção sertaneja; ditadura militar; Amazônia.

\section{Keywords}

Agroindustry;

hope;

country music; military dictatorship; Amazon. 